\title{
Developments in Services Producer Price Indices
}

\section{SUMMARY}

This article focuses on the development of price statistics in the service sector, in particular the work being done by the Office for National Statistics (ONS) to develop the Services Producer Price Indices (SPPIs) and the current plans for expanding the coverage of these indices.

\section{Introduction}

he service sector ${ }^{1}$ plays an important role in the UK economy, with

services (including those provided by government) accounting for approximately 75 per cent of UK Gross Domestic Product (GDP) (ONS, 2009a). Given the importance of this sector, users of economic statistics both within government and the wider community require comprehensive coverage of the service sector, particularly in the area of prices.

The Services Producer Price Indices (SPPIs) are primarily a suite of individual price indices that provide information on price change for a limited range of service industries. Each SPPI captures quarterly changes in the price received for services provided by UK businesses to other UK businesses and government. These individual price indices are also aggregated together to create an aggregate SPPI with limited coverage (Figure 1); this aggregate SPPI is not representative of the service sector as a whole due to the current limitations in coverage.

\section{Why are services important?}

The importance of the service sector has increased greatly over the last few decades as a result of an increase in its share of the economy. Service industries now dominate the UK economy, accounting for around three-quarters of UK Gross Domestic Product (GDP); this compares with twothirds as recently as 1995 (Figure 2).

As the service sector has grown, so has the demand for statistics in this area. SPPIs are one of a number of statistics produced by ONS and were developed to monitor price changes in what has long been the largest sector of the economy. One of their key uses is for deflation in the National Accounts where SPPIs are required to remove the effect of price changes in order to convert current price values to volumes. The SPPIs are used as deflators for the Index of Services and the quarterly measurement of Gross Domestic Product. The indices are also required by HM Treasury and the Bank of England to help monitor inflation in the economy by providing an indicator of upstream inflationary pressure. A key use of SPPIs is in the escalation of commercial contracts and they are also used for international comparison and monitoring.

\section{History of the SPPIs}

The Office for National Statistics (ONS) began development of a prototype price index for the service sector in the early 1990s. These initial price indices, known collectively as the Corporate Services Price Index (CSPI) as they collected prices for corporate services (those services purchased by businesses from other businesses), were developed as an extension of the well established Producer Price Index (PPI) for manufactured goods. The initial efforts concentrated on the collection of price data for a small number of relatively straightforward service industries where price collection methods used were very similar to those already in place for the PPI. This data was collected on a voluntary basis and covered just five industries with 


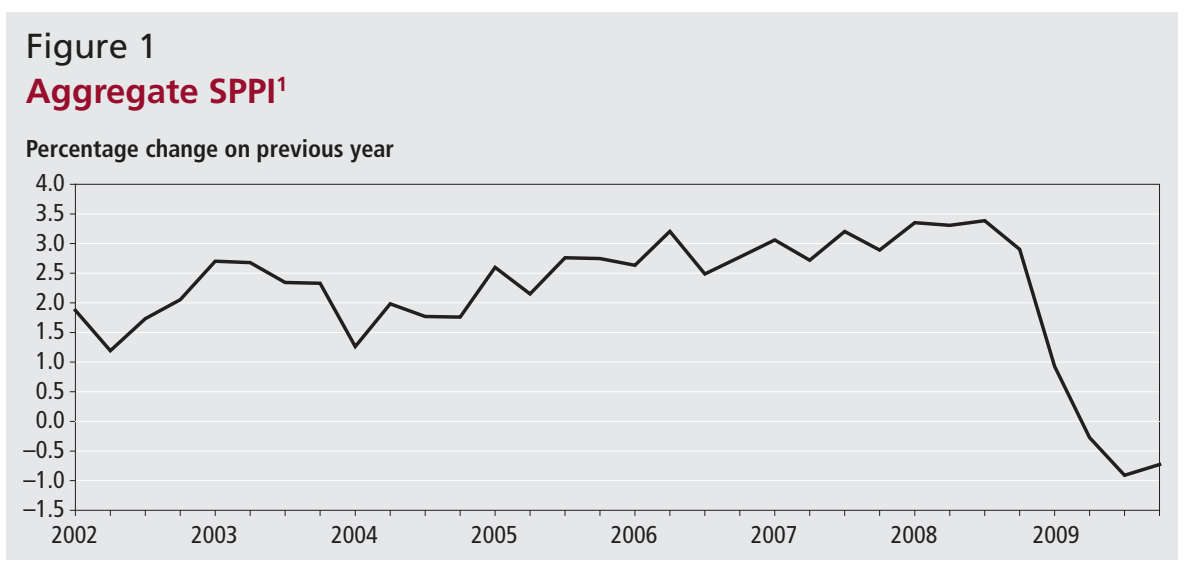

Note:

Source: Services Producer Price Indices

1 The aggregate SPPI is an aggregate of the individual industry level SPPIs produced and does not provide full coverage of the service sector.

\section{Figure 2 \\ Breakdown of UK gross value added (GVA) by sector}

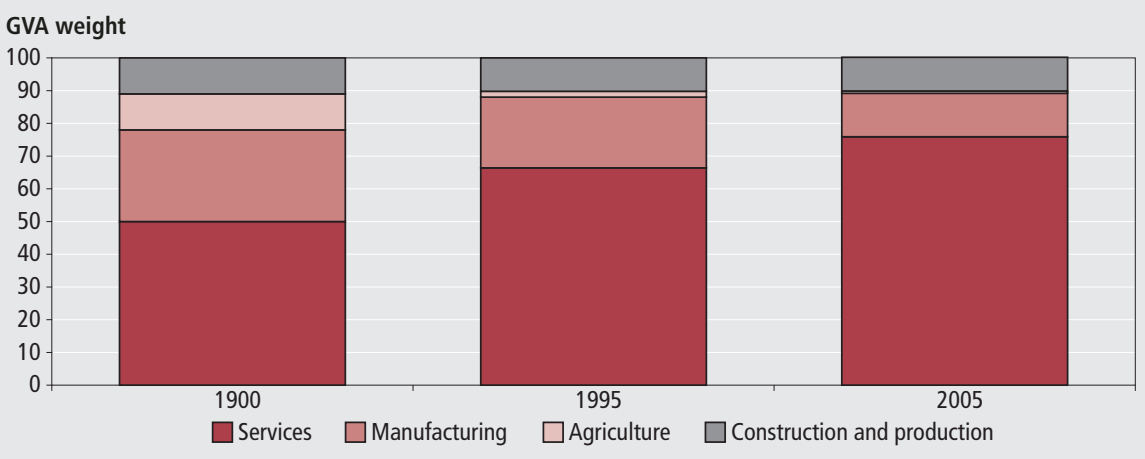

Source: ONS 2000a, 2000b, 2009b

approximately 150 companies providing data (Price, 1996).

In 1995, ONS established a dedicated team to take forward development of service sector prices. This development of the SPPIs was part-funded by the European Community, with the development of service sector prices also gaining momentum across Europe. With this extra resource in place, the number of indices developed and published gradually increased to 12 in 1998 (Skipper, 1998), with 22 industrial level indices being available in early 2000.

In November 2006, ONS changed the name of the CSPI to the Services Producer Price Indices (SPPIs). Since the development of price indices for the service sector had become more widespread across the international statistical community, this change brought the UK price index in line with equivalent series in other countries.

Since the initial development in the early 1990s, the SPPIs were classified as experimental statistics. The SPPIs were assessed as National Statistics by the UK Statistics Authority during the autumn of 2009. The published assessment report (UK Statistics Authority, 2009) determined that the SPPIs could be designated as a new National Statistics product subject to the implementation of a number of requirements which The Authority deemed essential to improve SPPI compliance with the Code of Practice for Official Statistics. A brief summary of the work carried out to meet these requirements include:

- clarification of the limited coverage of the SPPIs in published documents. The SPPI statistical bulletin and other published SPPI documents have been updated to ensure users are aware that the aggregate SPPI does not cover all services but is just an aggregate of the 32 component industrial industries published in the SPPI statistical bulletin

- the SPPI pages of the ONS website have been reviewed and updated to ensure SPPI metadata is more accessible. An SPPI mailbox has also been set up to allow users to provide comments regarding the website or the data (sppi@ons.gov.uk)

- full details of SPPI developments are being publicised, including a proposed work plan for ONS to become compliant with the European Short-Term Statistics regulation. This article covers these plans in detail and will be made available in their own right on the SPPI pages of the ONS website

- a detailed quality matrix for the current SPPI industries has been published on the SPPI pages of the ONS website that covers the methods used and metadata associated with each of the industrial SPPIs currently published by ONS

Following this, on 10 May 2010, the UK Statistics Authority Assessment Team accredited the SPPIs as a new National Statistic. The UK Statistics Authority has designated these statistics as National Statistics, in accordance with the Statistics and Registration Service Act 2007 and signifying compliance with the Code of Practice for Official Statistics.

Designation can be broadly interpreted to mean that the statistics:

- meet identified user needs

- are well explained and readily accessible

- are produced according to sound methods, and

- are managed impartially and objectively in the public interest

Once statistics have been designated as National Statistics it is a statutory requirement that the Code of Practice shall continue to be observed.

\section{Issues with service price development}

Since development of the SPPIs commenced, progress towards achieving comprehensive service sector coverage has been intermittent, partly due to funding issues, but in the main due to difficulties in the development of price indices for services. Most of these difficulties are not only experienced by ONS but also by National Statistics Institutes (NSIs) within the international statistical community and centre on difficulties in the measurement of service prices and the lack of supplementary information required to construct a price index.

The ultimate objective of any price index is to show changes in the price of a commodity or service at constant quality. The most appropriate method for measuring price change in such indices is to collect price data for well-specified, repeated products with observable transactions. This ideal lends itself particularly well to the manufacturing industry where there is a consistency in the product being produced allowing 
like-for-like comparisons in one period to the next. For example, monitoring the price of a loaf of bread over time is relatively straightforward as the specification (or more importantly quality) of a loaf of bread (such as weight and ingredients) is unlikely to change. This allows for the accurate measurement of price change over time as the quality of the product remains fixed.

However, for the service sector (and a handful of manufacturing industries) this method of measuring price change is often difficult to follow (Skipper, 1998). Many outputs provided by service industries are often unique and one-off in their nature. For instance, a set of architectural drawings for a building will only ever be designed once to the precise specifications of the customer. As a result, trying to obtain comparable prices for this service in subsequent periods is difficult as the exact same service will never be repeated. Furthermore, a number of service products are inherently difficult to measure due to the intangible nature of the service on offer. For example, the services offered by the legal industry such as legal advice and representation can be difficult to identify for the purposes of collecting price data. Even when the measurement of service prices is achieved there can be underlying quality issues which are particularly difficult to identify and measure. For example, if the price of a service can be accurately measured on the basis of the cost of time spent in service provision, a periodic adjustment will usually be required to account for any productivity gains which potentially offer an increased service for the same hourly rate.

As a result of these difficulties a number of different pricing methods have been developed by ONS and the international statistical community for use when it is not possible to directly observe repeated prices. In developing such price collection methods, a balance between what is conceptually desirable from the price index and what is achievable (in terms of resources available to the NSI and the industry that will potentially provide the information) needs to be struck. Table 1 summarises each of the pricing methods that have been developed for collecting prices in the service sector. The selection of the most appropriate method will depend on the pricing practice used within the target industry and the availability of this data from potential respondents.

In addition to the difficulties experienced in defining and collecting prices for the service sector, there is also a lack of supplementary data such as turnover at a detailed product level classification to help in the calculation of a price index (Sova et al, 2007).

The lack of a detailed product level classification for services is apparent in the 2008 revision of the Classification of Products by Activity (CPA) (Sova et al, 2007). This classification contains 124 pages, 72 of which are dedicated to manufactured goods and just 31 pages to the service sector (excluding other industries such as wholesale and construction). This is despite the fact that the service sector is over five times larger than the size of the manufacturing sector of the UK economy. This lack of detail is an issue that needs to be overcome at an early stage of development for a service price index and the method adopted by ONS is to develop its own service product classification in consultation with the industry. This method uses a recognised classification such as the Standard Industrial Classification (SIC) or $\mathrm{CPA}$ as a starting point and disaggregates each industry into a product level structure that groups similar services together. Other NSIs will tend to adopt a similar approach which can mean that below the aggregated industry level, international comparison of SPPIs is difficult.

A regular source of turnover data at a sufficient level of detail is needed to calculate weighting patterns for the price indices. As such a source is not available for the service sector as a whole, estimates of product level turnover are either collected directly when new price quotes are recruited to the SPPI, or as part of a dedicated turnover survey. This dedicated turnover survey, which is carried out every five years, is used solely to support the SPPI, and is therefore carried out on a relatively small scale, covering only those industries for which an SPPI is already produced.

For the manufacturing sector, the equivalent supplementary data is collected using the annual ProdCom survey. This survey (Production Communautaire, which is French for 'Community Production') is a statutory $\mathrm{EU}$ requirement and the detailed product level turnover collected is used to produce national estimates of the production of goods. This source of data provides the manufacturing price indices (PPIs) with product level turnover with which to calculate product weighting patterns, a detailed product level classification structure, known as the ProdCom Product List, to disaggregate each manufacturing industry and supplementary information to help in the development of a sampling frame. Despite numerous attempts (by various NSIs) to begin such a collection for the service sector, there is still no such tool available and there are no firm plans in place to begin the development of one; the difficulties in defining products for SPPIs are mirrored in turnover survey development.

The ONS Inter-Departmental Business Register (IDBR) is an effective sampling frame for many of the surveys carried out

\section{Table 1}

\section{Potential methods for collecting price data}

\begin{tabular}{|l|l|l|l|}
\hline $\begin{array}{l}\text { Unit of price } \\
\text { measurement }\end{array}$ & $\begin{array}{l}\text { Type of price } \\
\text { information }\end{array}$ & Pricing method & Description \\
\hline $\begin{array}{l}\text { Clearly specified } \\
\text { service }\end{array}$ & Price observed & $\begin{array}{l}\text { Direct use of } \\
\text { prices of repeated } \\
\text { services }\end{array}$ & Uses real transaction prices of the same service prices over time. Also includes prices of repeated contracts \\
\cline { 3 - 4 } & Unit value method & Estimates price using aggregate value and quantity data. \\
\cline { 2 - 4 } & $\begin{array}{l}\text { Price estimated } \\
\text { using relative } \\
\text { observed prices }\end{array}$ & $\begin{array}{l}\text { Component pricing } \\
\text { method }\end{array}$ & Price calculated as the sum of the prices of a number of independent output components \\
\cline { 2 - 4 } & $\begin{array}{l}\text { Percentage fee } \\
\text { method }\end{array}$ & $\begin{array}{l}\text { Estimates the price where a company bases the price of a service on a percentage of an asset value, good or service that the } \\
\text { service is connected to for example real estate }\end{array}$ \\
\cline { 2 - 4 } & Virtual prices & $\begin{array}{l}\text { Model pricing } \\
\text { method }\end{array}$ & $\begin{array}{l}\text { This method uses expert opinion to estimate a model price based on an actual transaction. The respondent provides an initial } \\
\text { price for an actual service transaction and then estimates the exact same transaction in future periods even though in reality the } \\
\text { service is not offered again. }\end{array}$ \\
\hline $\begin{array}{l}\text { Time spent } \\
\text { providing services }\end{array}$ & $\begin{array}{l}\text { Price observed or } \\
\text { estimated }\end{array}$ & $\begin{array}{l}\text { Time-based } \\
\text { methods }\end{array}$ & $\begin{array}{l}\text { Measures the price of the time spent in the provision of the service and not the price of the service itself. Used in industries } \\
\text { where the cost of the service corresponds directly or predominantly to the time in service provision for example legal services }\end{array}$ \\
\hline
\end{tabular}


by ONS. However, it includes insufficient detail to act as a sampling frame for price indices, as it is not possible to specify the individual goods or services produced by each company from the register. To overcome this issue in the manufacturing PPIs, ONS uses its ProdCom sample as a sampling frame but since there is no such sampling frame available for the service sector, the sample for the SPPIs is drawn directly from the IDBR. This can prove to be inefficient as there is no evidence to confirm that those potential companies selected actually produce the service in question. Again, supplementary investigation is required in the development of price indices for the service sector to ensure any sample is fit for purpose.

Despite these difficulties, international experience has shown that it is possible to make progress in the development of accurate price indices for the most difficult service industries and good progress has been made, not just in the UK, but across the international statistical community. Practical solutions to the difficulties encountered have been developed on a collaborative basis between NSIs, along with help from organisations such as Eurostat, (the statistical office for the European Union) and the Organisation for Economic Co-operation and Development (OECD). There are a number of international resources available to help with such developments and these include the International Monetary Fund (IMF) Producer Price Index manual, the Eurostat/ OECD methodological guide for developing SPPIs and a dedicated service sector working group known as the Voorburg Group. This working group, named after the city in which the first meeting was held, meets annually in response to a request from the United Nations Statistical Office (UNSO) (as it was then known) for assistance in developing service statistics. Further details on the work of the Voorburg group can be found via the dedicated website at http://stds.statcan.ca/english/ voorburg/. Eurostat have also set up an annual SPPI task force for the development of specific industrial SPPIs and have a dedicated website for member states to share development experiences and best practice.

\section{The ONS SPPIs - providing metadata and assessing quality}

ONS currently publishes 32 individual SPPIs. These individual indices measure changes in the prices received by UK businesses for services provided to other
UK businesses and, in total, represent approximately 52 per cent of this businessto-business activity. In addition to these industry level indices, two aggregate indices are also published. These indices represent the overall inflation of the services measured and are simply an aggregate of the individual industry level indices. The aggregate indices are calculated on both a net sector basis (including transactions between business services and all other sectors apart from business services) and a gross sector basis (including all business service transactions).

As discussed earlier, depending upon the nature of a particular industry and the way in which companies within that industry price for their services, different pricing methods may be used to monitor price change and, as a result, each individual industry level SPPI may vary in the way it is calculated. In addition to this, the individual indices may also differ in the source used to collect prices. The main source of price data used to calculate SPPIs is a quarterly questionnaire which is sent out to a fixed panel sample of companies. However, for some service industries, a source of price data may already be collected by a third party. Where such data is collected by a reliable source and can be deemed as sufficient quality, it may be used to calculate the price index as an alternative to sending out questionnaires to companies. Using this third party data not only reduces the amount of resource required by ONS to process the questionnaires but it also reduces the amount of burden placed on respondents by questionnaires. Currently, the SPPIs utilise regulatory data such as that collected by the Office for Communications (OfCom) in the SPPI for business telecommunications and industry data such as that collected by the Investment Property Databank (IPD) in the property rentals SPPI.

Whilst many aspects of SPPI methodology are well communicated in various documents such as the Triennial Review (ONS, 2009c) and the SPPI Summary Quality Review (ONS, 2009d), these documents tend to summarise the methodology used across all indices but do not attempt to highlight the differences between the industry-level indices. In order to make users aware of these differences in price collection and pricing methods and also to highlight any limitations in terms of coverage or conceptual issues, a quality matrix has been put together and can be accessed via the ONS website at www. statistics.gov.uk/CCI/article.asp? $\mathrm{ID}=2417$. For each individual index, this matrix includes information on the price collection method used, the number of quotes received and the number of respondents that provide these quotes.

\section{Expanding coverage}

The need for more comprehensive industrial coverage of service sector prices is a key requirement of users of the data in the UK. In addition to this, there is also a statutory requirement to supply quarterly price data on selected service industries to Eurostat as part of the European Short Term Statistics (STS) Regulation (number 1165/98) published on 19 May 1998. Initially, this regulation covered service statistics by turnover and employment variables only, however on 6 July 2005 , the regulation was amended (number $1158 / 2005$ ) to include output prices for a number of service industries. STS indicators facilitate decision-making and are tools for formulating and monitoring the economic and monetary policy of the European Union and the euro area. ONS currently supplies the majority of SPPIs required for this regulation, but needs to develop indices for a further ten industries to become fully compliant.

To attempt to take forward this expansion of the SPPIs and therefore meet the needs of customers in both the UK and Europe, funding was made available to set up a development team to investigate collecting prices in additional industries. The team was recruited at the beginning of 2009 and has since begun the research and development of price collection for ten industries. The choice of industries to develop was determined in consultation with key stakeholders and since the priorities of these stakeholders matches closely with the requirements of Eurostat, this development will also ensure that ONS is compliant with the STS regulation.

If successful, the development of new price indices (whether for manufacturing or service sector) can take up to two years before an index is ready for dissemination and depends largely upon the complexity of the industry and the availability of auxiliary information such as turnover data for the industry in question. In most cases, such developments follow a framework that has been recommended internationally in the Producer Price Index Manual (Chapter 1, Appendix 1.1, paragraph 1.282-1.384). Table 2 summarises the development framework for price indices that has been adapted for use in the development of ONS SPPIs and the suggested activities involved at each stage of the development. 
Table 2

Framework for the development of Service Price Indices

\begin{tabular}{|c|c|c|}
\hline Development stage & Objectives & Approximate timescale \\
\hline 1. Initial industry research & $\begin{array}{l}\text { This stage of development identifies the conceptual requirements and development scope for the new SPPI and will include } \\
\text { reviewing any similar developments carried out by other National Statistics Institutes (NSIs). }\end{array}$ & $1-2$ months \\
\hline 2. Industry consultation & $\begin{array}{l}\text { The purpose of this stage is to gain a better understanding of the industry being developed. This will include consultation with } \\
\text { industry experts and trade associations to try and identify the most suitable method of monitoring prices in the industry and the } \\
\text { draft development of a product level aggregation structure for the industry. A key objective in this stage is to try and identify a } \\
\text { source of data that could potentially be used to calculate a suitable price index. }\end{array}$ & $2-3$ months \\
\hline $\begin{array}{l}\text { 3. Development and testing } \\
\text { of data collection instrument }\end{array}$ & $\begin{array}{l}\text { With a product level aggregation structure and method of price collection identified in the previous stage, this next stage will } \\
\text { focus on the development and testing of questionnaires to collect the price data. This will be an iterative process with draft } \\
\text { questionnaires being tested in the field with potential respondents and updated taking account of feedback. Further work will } \\
\text { also take place to develop the methodology and systems required to process any new price data and calculate the price index. }\end{array}$ & $4-6$ months \\
\hline 4. Recruitment phase & $\begin{array}{l}\text { This stage is where the new questionnaires are sent out to potential respondents to 'recruit' price data to the SPPI. The } \\
\text { recruitment will cover a calendar quarter with data being processed and validated to ensure any price data being returned is } \\
\text { suitable for use in the final price index. Prior to the despatch of the recruitment questionnaire, a suitable sample of potential } \\
\text { respondents will be designed. }\end{array}$ & 3 months \\
\hline 5. Pilot data collection & $\begin{array}{l}\text { Having collected this initial price data during the recruitment phase, the draft SPPI will now continue with regular quarterly data } \\
\text { collection whereby respondents from the recruitment phase will be asked to provide quarterly updates for the price data they } \\
\text { provided. It is recommended that at least four quarters worth of data is collected to assess the suitability and quality of the data } \\
\text { being returned. At the end of this stage, a decision will be made on the suitability of the new SPPI for publication. The new SPPI } \\
\text { will either be published as a development index or further work will be required to improve any deficiencies. }\end{array}$ & 12 months \\
\hline
\end{tabular}

Source: Office for National Statistics

Table 3

\section{Summary of development progress for phase one industries}

\begin{tabular}{|c|c|}
\hline Industry & Development progress \\
\hline Cargo handling & $\begin{array}{l}\text { Initial recruitment questionnaires were despatched for this industry in March 2010. During the research of this industry it was identified that potential } \\
\text { respondents would be able to provide actual prices for repeatable transactions. Therefore the price method being used is direct use of repeated prices (see } \\
\text { Table 1). }\end{array}$ \\
\hline Legal Services & $\begin{array}{l}\text { Previous attempts to develop a price index for legal services by ONS had been unsuccessful due to the difficulty in collecting regular price data. The current } \\
\text { research and development has identified that data collection based on time-based methods (see Table 1) can potentially be used. Questionnaires have been } \\
\text { developed and tested with potential respondents and final versions were despatched in March } 2010 \text { to commence initial recruitment of data. }\end{array}$ \\
\hline Accountancy & $\begin{array}{l}\text { As with legal services, previous attempts to develop a price index in this industry had proved unsuccessful. Following consultation with the industry it has been } \\
\text { identified that two methods of price collection may be suitable in the accountancy industry. The first will be the direct use of repeated prices and this will be } \\
\text { used for smaller respondents (those with less than } 100 \text { employees). For the larger respondents (those with more than } 100 \text { employees) the consultation showed } \\
\text { that the only price method that would potentially be suitable is a time-based method (see Table 1). Questionnaires have been developed and tested based on } \\
\text { these two methods and were despatched in March } 2010 \text {. }\end{array}$ \\
\hline Architecture and Engineering & $\begin{array}{l}\text { The development of these industries has shown similar results to that for legal services. In consultation with the industry it has been identified that the } \\
\text { only potential method for the collection of price data is through the use of a time based method. Questionnaires have been developed and tested and were } \\
\text { despatched in March } 2010 \text {. }\end{array}$ \\
\hline Air Freight Transport & $\begin{array}{l}\text { ONS, along with colleagues from other National Statistics Institutes in Europe, has identified a potential source of third-party data which could be used to } \\
\text { calculate a price index in this industry using a unit value method of price calculation (see Table 1). An initial sub-set of data was purchased late in } 2009 \text { and is } \\
\text { being tested by ONS to determine its suitability. Following this testing, further work may be required to resolve any quality issues. If the draft index is deemed } \\
\text { unsuitable, a contingency will be to collect price data via the standard method of questionnaires. }\end{array}$ \\
\hline
\end{tabular}

Source: Office for National Statistics

Using this framework, the SPPI development project has been planned over a three year period (Financial Year (FY) 2009/10 to FY 2011/12) and has been split into two phases of development, each consisting of the development of indices for five industries. Phase one of this project, which commenced in April 2009, covers the development of: cargo handling; legal activities; accountancy services; architecture and engineering and air freight transport. The progress of this work and the methods used can be seen in Table 3 and, as shown in the table, initial recruitment of companies and collection of price data has now began.

The second phase of development, which coincides with the data collection of phase one industries, will follow a similar approach as defined by the framework above and commenced in March 2010. During this phase of the project, indices will be developed for: business and management consultancy; storage and warehousing; data processing; computer programming and advertising creation.

A detailed work plan for the remainder of the SPPI development project (from March 2010 onwards) is provided in Table 4. Assuming the development progresses to timetable, phase one industries will be ready for initial dissemination in May 2011 (either via a web article or as supplementary development indices in the SPPI statistical bulletin), with the industries being developed in phase two following in May 2012. Once ONS is content with their quality (this will include assessing the quality of data being returned, comparisons of the calculated price indices with other data sources and discussions with customers and industry experts) they will be published as part of the regular quarterly SPPI statistical bulletin and weighted into the aggregate SPPI.

\section{Forthcoming plans for service sector prices}

In addition to the plans to develop new price indices to improve the industrial coverage of the SPPIs, ONS is currently planning the next SPPI turnover survey, to collect updated product-level turnover in respect of 2010 with which the SPPI weighting structure can be updated. The most recent SPPI turnover survey was undertaken in 2006 (with a reference period of 2005) and saw questionnaires sent to some 5,000 businesses covering 25 separate service industries. The initial plan for the 2010 SPPI Turnover Survey is to expand both the sample size and the number of industries included. The majority of the additional industries to be included in the 2010 survey will be those in which ONS is 


\section{Table 4}

\section{Work plan for the SPPI development project (March 2010 onwards)}

\begin{tabular}{lll}
\hline Development & Description of task & Provisional Timeframe \\
\hline Phase 1 & $\begin{array}{l}\text { 1. Recruitment of initial quarter (Q1 2010) price data for phase } 1 \text { industries } \\
\text { Including the dispatch of questionnaires, data collection, data processing/validation and quality assurance of methods }\end{array}$ \\
$\begin{array}{ll}\text { Development of price indices } \\
\text { for: }\end{array}$ & $\begin{array}{l}\text { 2. Pilot quarterly data collection for new industries (recommended four quarters data collection) } \\
\text { Regular quarterly collection of updated price data from respondents recruited in Q1. Including the quality assurance and }\end{array}$
\end{tabular}

Accountancy;

Legal services;

Air freight;

validation of data being received along with any further developments to rectify problems or issue.

Architecture \& Engineering; $\quad$ Decision on most appropriate method to be decided. Potentially new industrial SPPIs will be published in the form of an article

Cargo Handling. covering the development, methods, results and quality. Consultation with users to take place.

April to May 2011

4. Continued quarterly data collection and publication

April 2011 onwards

Regular quarterly data collection for new industries and publication of data as supplementary tables in quarterly SPPI statistica

Bulletin. Quality assessment of new industrial SPPIs will continue. New SPPIs will be weighted into the aggregate SPPI series once quality of data has been assured.

\begin{tabular}{ll}
\hline Phase 2 & $\begin{array}{l}\text { 1. Initial research of new industries } \\
\text { Including researching methods used by other National Statistics Institutes and defining the conceptual requirements of the } \\
\text { Development of price indices }\end{array}$ \\
industrial SPPI and identifying suitable price collection methods for testing.
\end{tabular}

March to April 2010

Development of price indices industrial SPPI and identifying suitable price collection methods for testing.

for:

Computer programming;

Data processing;

2. Development of data collection questionnaire

Advertising creation

Business \& management

consultancy;

Storage \& Warehousing.

Design of initial data collection questionnaire for iterative testing within each industry. This stage will also include

May 2010 to February 2011 methodological work to design and select a sample of respondents for the live data collection, quality assure and test the methods to be used in the index calculation and develop the computer system for data processing/validation.

3. Recruitment of initial quarter (Q1 2011) price data for phase 1 industries

Including the dispatch of questionnaires, data collection, data processing/validation and quality assurance of methods

March 2011 to June 2011

4. Pilot quarterly data collection for new industries (recommended four quarters data collection)

June 2011 to April 2012

Regular quarterly collection of updated price data from respondents recruited in Q1. Including the quality assurance and validation of data being received along with any further developments to rectify problems or issue.

5. Initial dissemination of new industrial price indices

Decision on most appropriate method to be decided. Potentially new industrial SPPIs will be published in the form of an article covering the development, methods, results and quality. Consultation with users to take place.

Table 5

\section{High level plan for the 2010 SPPI turnover survey}

\begin{tabular}{|c|c|}
\hline Date & Task \\
\hline April 2010 & Project start up including agreeing the scope and coverage of the 2010 SPPI turnover survey. \\
\hline May - December 2010 & $\begin{array}{l}\text { Development of turnover questionnaires. This will include the review and development of product level structures for each industry to be included along with } \\
\text { testing each of the questionnaires with the industry. }\end{array}$ \\
\hline December 2010 - April 2011 & $\begin{array}{l}\text { Development of methodology and IM systems to process the } 2010 \text { SPPI turnover data (including validation rules, weighting and estimation). Sample design and } \\
\text { selection in readiness for the despatch of questionnaires. }\end{array}$ \\
\hline June - October 2011 & Data collection - this will include the despatch of questionnaires (end April 2011) to collect turnover (in respect of 2010), data validation and processing. \\
\hline October - December 2011 & $\begin{array}{l}\text { Quality assurance of data and preparation for re-calculating SPPI product level weights using the } 2010 \text { turnover. Article detailing the } 2010 \text { Turnover Survey } \\
\text { results to be published. }\end{array}$ \\
\hline
\end{tabular}

Source: Office for National Statistics

also developing new price indices. However, further investigation will be carried out to try and identify service industries outside the above SPPI development to include in the 2010 Turnover survey.

A project to take forward the 2010 SPPI turnover began April 2010. An initial highlevel plan for the survey is shown in Table 5 (subject to change).

\section{Conclusion}

The aim of this article was to highlight the difficulties associated with the development of price indices for the service sector and to publicise the progress and methods being used by both the Office for National Statistics and other National Statistics Institutes across the international statistical community. Fundamental to price index development is the need to strike a balance between what the price index is conceptually required to measure and the availability of data or methods to meet these needs. For the service sector, striking this balance can be difficult, largely due to the nature of many service industries and the lack of availability of the supplementary data required to assist with the calculation of price indices. As a result of these difficulties, progress towards the comprehensive coverage of this sector has been intermittent, despite the clear importance of the sector to the UK economy.

This article has also provided an overview of the SPPIs currently published by ONS, and the work being carried out to expand coverage of the SPPIs into new industries. Further articles will be published to document the progress of this development work to ensure that all users are kept up to 
date with the progress being made. Firm dates and the proposed format for the first publication of these newly developed indices will also be publicised when they are available.

\section{Note}

1 The service sector covers sections $\mathrm{G}$ to $\mathrm{S}$ of the Standard Industrial Classification (SIC).

\section{CONTACT}

Chris Jenkins

(《) christopher.jenkins@ons.gov.uk

(C) 01633455474

Tracy Jones

凶x tracy.jones@ons.gov.uk

(C) 01633 456571)

\section{REFERENCES}

ONS (2000a) United Kingdom National Accounts: The Blue Book at www.statistics.gov.uk/downloads/theme economy/BB_2000.pdf
ONS (2000b) United Kingdom Economic Accounts, No. 32, Q3 2000 at WWw.statistics.gov.uk/downloads/theme_ economy/UKEA_Q3_2000.pdf

ONS (2009a) United Kingdom National Accounts: The Blue Book at www.statistics.gov.uk/downloads/theme economy/BB09.pdf

ONS (2009b) United Kingdom Economic Accounts, No. 68, Q3 2009 at www.statistics.gov.uk/downloads/theme_ economy/UKEA_09q3.pdf

ONS (2009C) Report on the Triennial Review of the Producer and Trade Price Indices and the Service Producer Price Indices Surveys at www.statistics.gov.uk/articles/ppi/PPITriennial-Review-Report-2009.pdf

ONS (2009d) Summary Quality Report for Services Producer Price Indices at www.ons.gov.uk/about-statistics/ methodology-and-quality/quality/qual-infoeconomic-social-and-bus-stats/quality-reportsfor-business-statistics/summary-quality-reportfor-services-producer-price-indices.pdf
Price J (1996) 'Producer Prices for Services: Development of a New Price Index', Economic Trends 513 pp 14-18

Skipper H (1998) 'Development of the Corporate Services Price Index: A review of progress', Economic Trends 538 pp 25-31

Sova M, Wood J and Richardson I (20070 'Challenges in the estimation and quality assessment of services producer price indices. Statistics in Transition 8 (3) pp 519-524

UK Statistics Authority (2009) 'Assessment of Services Producer Price Indices produced by the Office for National Statistics', Assessment Report 25 at

www.statisticsauthority.gov.uk/assessment/ assessment-reports/index.html 